JURNAL KETAHANAN NASIONAL

Vol. 24, No.2, Agustus 2018, Hal 135-151

DOI:http://dx.doi.org/ 10.22146/jkn.33573

ISSN:0853-9340(Print), ISSN:2527-9688(Online)

Online sejak 28 Desember 2015 di :http://jurnal.ugm.ac.id/JKN

VOLUME 24

No. 2, Agustus 2018

Halaman 135-151

\title{
Hakikat Adil Dan Makmur Sebagai Landasan Hidup Dalam Mewujudkan Ketahanan Untuk Mencapai Masyarakat Sejahtera Melalui Pembangunan Nasional Berdasarkan Pancasila
}

\author{
Sudjana \\ Fakultas Hukum Universitas Padjadjaran \\ sdjana@yahoo.com
}

\begin{abstract}
This article examined the nature of prosperousness as the foundation of life of the Indonesian nation towards a prosperous society so that a philosophical approach was realized in a practical level (operational) through the national development.

The research used the method of approach philosophical; stages of research, the study of literature; and data analysis, descriptive philosophical.

The study results could be stated that fairness and prosperousness were terms that could not be separated, even though both of them were the object of study of science that it was different. Fairness or justice was the study of law and one of the objectives of the law while the prosperousness focused on meeting basic human needs. It was one of economic studies. Fair and prosperous were related to the time, place and the philosophy was adopted by a group of people who called himself as a country. Thus the implementation of both institutions in national development must be understood in the context and could not be separated from the culture, ideology, philosophy of life and philosophy of the nation that was followed. The essence of prosperousness based on Pancasila was social justice and social prosperity through national development in all fields for all the people of Indonesia proportionally and equally and it was inspired by the values of Pancasila unanimously and intactly.
\end{abstract}

Keywords: Fair and Prosperous, Prosperous Society, National Development, Pancasila

\begin{abstract}
ABSTRAK
Kajian ini membahas hakikat adil dan makmur sebagai landasan hidup bangsa Indonesia menuju masyarakat yang sejahtera, sehingga pendekatannya lebih bersifat filosofis tetapi kemudian diwujudkan dalam tatanan praktis (operasional) melalui pembangunan nasional.

Metode penelitian yang digunakan yaitu metode pendekatan filosofis; tahap penelitian, studi kepustakaan; dan analisis data, deskriptif filosofis.

Hasil kajian yang dapat dikemukakan adalah bahwa adil dan makmur adalah istilah yang tidak dapat dipisahkan, meskipun kedua hal tersebut merupakan obyek kajian dari ilmu yang berbeda. Keadilan atau adil adalah kajian hukum dan merupakan salah satu tujuan dari hukum, sedangkan makmur lebih menitikberatkan pada pemenuhan kebutuhan pokok manusia, sehingga merupakan kajian ekonomi. Adil dan makmur bersifat relatif, bergantung pada waktu, tempat serta falsafah yang dianut oleh sekelompok masyarakat yang kemudian menamakan dirinya sebagai negara. Dengan demikian penerapan kedua pranata tersebut dalam pembangunan nasional harus dipahami dalam konteks yang tidak dapat dipisahkan dari budaya, ideologi, pandangan hidup serta falsafah bangsa yang dianutnya. Hakikat adil dan makmur berdasarkan Pancasila merupakan keadilan sosial dan kemakmuran sosial melalui pembangunan nasional di segala bidang untuk seluruh rakyat Indonesia secara proporsional (sebanding) dan merata yang dijiwai oleh nilai-nilai Pancasila secara bulat dan utuh.
\end{abstract}

Kata Kunci : Adil dan Makmur, Masyarakat Sejahtera, Pembangunan Nasional, Pancasila 


\section{PENGANTAR}

Indonesia menganut konsepsi negara hukum dalam arti luas (rechtstaat in ruimezin) yang menitikberatkan pada penyelenggaraan kepentingan umum sekaligus mewujudkan kesejahteraan rakyat (welfare state). Sebagai negara hukum yang menganut falsafah Pancasila, Indonesia bertekad untuk mencapai tujuan pembangunan nasional dengan mengutamakan keadilan dan kemakmuran untuk mewujudkan kesejahteraan lahir batin bagi seluruh rakyat Indonesia sebagaimana tercantum dalam Pembukaan Undang-Undang Dasar 1945 Alinea IV.

Dalam merealisasikan tujuan tersebut, hukum berperan untuk mengatur kehidupan agar berjalan dengan tertib dan teratur serta diusahakan sedemikan rupa sehingga hasil-hasil pembangunan yang telah dicapai dapat dirasakan secara proporsional dan setiap individu dapat memenuhi kebutuhan hidupnya. Dengan demikian aspek ketertiban, keadilan dan kesejahteraan dalam masyarakat merupakan tujuan pokok dari kaidah hukum. Kaidah hukum sangat diperlukan dalam kehidupan masyarakat, hal ini didasarkan atas pertimbangan bahwa : (1). Kaidah hukum bersifat tegas apabila kaidah atau norma lainnya tidak ditaati padahal kepentingan masyarakat menghendaki pentaatan kaidahkaidah tersebut; (2). Dikaitkan dengan perkembangan masyarakat itu sendiri yang begitu cepat, timbulah berbagai macam kepentingan yang tidak diatur oleh kaidahkaidah lainnya; (3). Mempunyai sanksi yang diatur secara formal dalam berbagai peraturan perundang-undangan (Hutagalung, 1999: 13).

Konflik kepentingan yang timbul dalam pergaulan masyarakat, pemecahannya tidak semata-mata berdasarkan kekuatan, seperti dalam Teori Hobbes (leviathan) yaitu Homo homoni lupus (Manusia adalah srigala bagi manusia lainnya) dan Bellum omnium contra omnes (Manusia selalu berperang dengan sesamanya), melainkan berdasarkan atas ketentuan yang berorientasi pada kepentingankepentingan dan nilai-nilai obyektif yang disebut keadilan (Hutagalung, 1999: 14). Sedangkan orientasi yang berdasarkan pada kebutuhan dan nilai-nilai subyektif disebut kemakmuran. Kedua orientasi tersebut pada hakikatnya adalah sebagai landasan hidup manusia dalam mewujudkan masyarakat sejahtera yang pelaksanaannya dilakukan melalui pembangunan nasional yaitu perubahan ke arah yang lebih baik (progresif) dalam perspektif bangsa untuk meningkatkan kualitas hidup. jadi, inti dari pembangunan nasional adalah peningkatan harkat dan martabat masyarakat Indonesia berdasarkan pada nilainilai hakikat kodrat manusia yaitu aspek rohani dan jasmani, aspek individu dan makhluk sosial, yang pada gilirannya dijabarkan dalam berbagai bidang pembangunan (Kaelan, 2000: 236).

Keadilan sebagai konsep hukum senantiasa dikaitkan dengan kemakmuran (konsep ekonomi), sehingga melahirkan istilah yang lazim disebut adil dan makmur. Pengertian adil dimaksudkan dalam lingkup kehidupan bersama dalam pemenuhan hak dan kewajiban baik dalam bidang hukum maupun moral, sedangkan pengertian makmur adalah tercapainya pemenuhan kebutuhan hidup. Perpaduan antara adil dan makmur sebagai landasan hidup direalisasikan melalui pembangunan nasional yang terpadu dan menyeluruh sehingga akan melahirkan masyarakat Indonesia yang sejahtera atau kesejahteraan umum sebagaimana tujuan nasional yang tercantum dalam Alinea IV Pembukaan UUD 1945. Hal ini berarti bahwa setiap warga negara dapat mencapai kesejahteraan lahir batin sesuai dengan 
haknya, sehingga dapat menikmati secara aman dan tentram tanpa mendapat gangguan. Berdasarkan pemikiran tersebut, kesejahteraan umum mempunyai makna adanya pengakuan hak-hak asasi semua warga negara (Hutagalung, 1999: 48). Keadilan sebagai hasil pola pikir masyarakat dipengaruhi oleh kondisi dan situasi budaya setempat sehingga maknanya dapat berbeda-beda, sedangkan kemakmuran tergantung kepada persepsi seseorang terhadap kehidupannya karena sifat manusia yang selalu tidak puas meskipun pemenuhan kebutuhan (needs) sebenarnya telah terpenuhi, namun keinginan (wants) akan selalu berubah dan berkembang. Selain itu, keadilan, kemakmuran, dan sejahtera juga dipengaruhi oleh pandangan hidup tentang nilai-nilai tersebut dari warga masyarakat yang bersangkutan, sehingga konsep-konsep tersebut dalam realitanya akan berbeda karena berlainan pandangan hidupnya.

Bangsa Indonesia mempunyai suatu pandangan hidup bersama (Pancasila) yang bersumber pada budaya dan nilai-nilai religiusnya sehingga diyakini akan mampu memecahkan masalah yang dihadapinya secara tepat serta merupakan pedoman untuk mencapai tujuan yang dikehendaki yaitu adil dan makmur. Hal ini disebabkan Pancasila mengandung konsepsi dasar mengenai kehidupan yang dicita-citakan dan menyangkut gagasan mengenai wujud kehidupan yang dianggap baik untuk seluruh rakyat Indonesia yakni masyarakat sejahtera.

\section{PEMBAHASAN}

\section{Hakikat Adil Dan Makmur Sebagai Landasan Hidup Manusia}

Hakikat keadilan sudah dipermasalahkan oleh tokoh-tokoh pemikir Yunani, seperti Socrates, Plato, Aristoteles, dan Kaum
Stoisme. Misalnya masalah keadilan telah menguasai syair-syair Hesiod dan Solon pembuat Undang-Undang Atica. Keduanya meminta pertolongan dari Dike putri Zeus sebagai penjamin keadilan terhadap tirani dunia, pelanggaran hak-hak dan tidak adanya keadilan sosial. Solon menggambarkan Dike, sebagai seorang dewi yang menghukum kekacauan dan ketidakadilan dengan kejahatan-kejahatan sosial (social evil), sedang masyarakat yang adil dianugrahi dengan perdamaian, kemakmuran, dan kesejahteraan (Friedmann, 1960: 6). Sejak itu pula timbulah hubungan antara keadilan dan hukum positif yang menguasai alam pikiran bangsa Yunani dan dalam hakikatnya semua pemikiran tentang hukum (Hutagalung, 1999: 33-34).

Menurut filsafat hukum, keadilan dicari hakikat sumber keberadaanya. Plato dan Aristoteles menjelaskan definisi yang lebih konkrit tentang pengertian keadilan dan hubungannya dengan hukum positif. Plato mengasalkan konsepsinya tentang keadilan dari inspirasi, sedang Aristoteles mendekatinya dengan analisis yang berdasarkan ilmu dan prinsip-prinsip rasional dengan latar belakang tipe masyarakat politik dan peraturan-peraturan hukum yang ada pada waktu itu. Sebagai landasan yang menghubungkan keduanya adalah concept of virtue, yaitu sifat baik, yang mencakup segalanya dan keadilan merupakan bagiannya. Berdasarkan concept of virtue lahirlah pengertian balance dan harmoni, sebagai suatu ukuran pada masyarakat dan perorangan yang adil.

Plato berpendapat bahwa harmoni adalah suatu keadaan balance pikiran (mind) dari dalam yang tidak dapat dianalisis oleh akal. Sedangkan menurut Aristoteles, harmoni berada di tengah-tengah antara dua 
keadaan yang ekstrim, dan dihasilkan dengan menggunakan prinsip-prinsip yang mirip dalam dasar-dasar ilmu pasti yaitu campuran keadaan ekstrim dalam pemerintahan dengan hubungan antara perorangan (Friedmann, 1960: 7). Pandangan Plato ini berkaitan dengan ajarannya mengenai pembagian jiwa manusia (Plato's doctrine of the threeparts of soul) (Lee, 1960: 184) yang mengatakan bahwa jiwa manusia dibagi ke dalam tiga bagian sesuai dengan kemampuan kodrati yang dimilikinya dan berbeda dengan makhluk lainnya, yaitu (1). Pikiran atau akal (nous) yang merupakan bagian rasional, (2). Semangat atau keberanian (thumos), dan (3). Keinginan, nafsu atau kebutuhan (epithumia) (Rapar, 1988: 75). Trikhotomi jiwa manusia itu oleh Plato dihubungkan dengan empat macam pokok kebajikan yang disebut moralitas jiwa (soul morality) atau keutamaan (exellence) (Rapar, 1988: 76). Keempat kebajikan itu adalah pengendalian diri, keperkasaan, kebijaksanaan atau kearifan, dan keadilan. Pikiran dihubungkan dengan kebijaksanaan, semangat atau keberanian dengan keperkasaan, sedangkan keinginan, nafsu atau kebutuhan dengan pengendalian diri. Ketiga bagian jiwa tersebut secara keseluruhan dihubungkan dengan keadilan sebagai salah satu kebajikan pokok individu dan masyarakat sehingga dapat memelihara keseimbangannya. Keadilan menghubungkan ketiga macam kebajikan pokok lainnya, yaitu pengendalian diri, kebijaksanaan, dan kearifan. Dengan demikian bagi Plato, keadilan bukanlah konsep hukum (Rapar, 1988: 81). Akhirnya Plato berpendapat terdapat keadilan individual yaitu individu dapat menguasai dan mengendalikan diri sesuai dengan panggilannya yang ditentukan oleh bakat, kemampuan dan ketrampilan.
Kemudian keadilan dalam negara didasarkan atas kebutuhan dan keinginan manusia yang banyak dan beragam dalam kehidupan seharihari. Manusia tidak mampu untuk memenuhi kebutuhan ini tanpa bantuan oran lain, karena itu lalu mengadakan kerjasama, maka terbentuklah suatu negara. Dengan demikian negara terbentuk karena adanya kebutuhan dan keinginan yang beraneka ragam, karena itu perlu adanya kerjasama sesuai dengan bakat, bidang keahlian dan ketrampilan masingmasing. Dengan demikian, keadilan bagi Plato adalah pembagian kerja yang diatur oleh bakat, keahlian dan ketrampilan setiap warga negara (Rapar, 1988: 83-84).

Aristoteles dalam teori hukumnya, memformulasikan keadilan ke dalam (Friedmann, 1960:10): Distributive, yaitu keadilan yang membagi, memberi petunjuk tentang pembagian barang dan kehormatan kepada masing-masing orang menurut tempat di masyarakat sesuai perlakuan sama menurut hukum. Corrective atau remedial justice (keadilan yang memperbaiki), yaitu prinsipprinsip teknis yang mengatur administrasi hukum, dalam arti untuk mengatur hubungan hukum harus ada suatu ukuran yang umum guna memperbaiki akibat-akibat tindakan tanpa memperhatikan siapa orang berkepentingan untuk keperluan tersebut, berarti tindakantindakan itu harus diukur secara obyektif (Dias, 1976: 66).

Sidharta (2003: 6) dengan mendasarkan kepada pendapat Aristoteles membedakan keadilan dalam beberapa aspek, yaitu (1). Keadilan distributif (Iustitia distributiva) adalah keadilan yang berupa kewajiban pimpinan masyarakat untuk memberikan kepada warga masyarakat beban sosial, fungsifungsi, balas jasa dan kehormatan secara proporsional (seimbang) dengan kecakapan dan 
jasa masing-masing. (2). Keadilan komutatif (Iustitia commutativa) adalah keadilan yang berupa kesenilaian antara prestasi dan kontra prestasi, antara jasa dan balas jasa dalam hubungan antar warga, atau dilihat dari sudut pemerintah memberikan kepada setiap warga secara sama tanpa menghiraukan perbedaan keadaan pribadi ataupun jasa. (3). Keadilan vindikatif(Iustitia vindicativa) adalah keadilan yang memberikan hukuman sesuai dengan kesalahan yang bersangkutan. (4). Keadilan protektif (Iustitia protective) adalah keadilan berupa perlindungan yang diberikan kepada setiap manusia, sehingga tidak seorangpun mendapat perlakuan sewenang-wenang. (5). Keadilan legalis (Salman, 1987: 10), yaitu keadilan yang ingin diciptakan oleh undangundang.

Para ahli lainnya seperti Cephalos berpendapat bahwa keadilan adalah kejujuran, Polemarchos mengatakan bahwa keadilan ialah memberikan kepada setiap orang apa yang menjadi haknya, dan Thrasymachos berpendapat bahwa keadilan tidak lain adalah keuntungan bagi yang kuat (Justice is nothing but the advantage of stronger) (Rapar, 1988: 82). Sedangkan menurut kaum teoritisi hukum alam, hakikat keadilan itu ditafsirkan secara berbeda. Keadilan dipahami sebagai hal tertinggi atau terakhir yang berkembang dari sifat alam semesta yaitu Tuhan dan akal manusia. M.T. Cicero (Sabine, 1977: 160164) mengatakan bahwa keadilan adalah suatu kebaikan yang hakiki. Ulpianus (Sabine, 1977: 169) berpendapat bahwa keadilan adalah penentuan yang pasti dan mengikat untuk memberikan pada tiap orang haknya. Thomas van Aquinas (Sabine, 1977: 246) mengatakan bahwa keadilan adalah kemauan, yaitu untuk memberikan setiap orang yang menjadi haknya, serta membedakan antara keadilan umum (iustitia generalis) yakni keadilan yang mengatur hubungan bagian terhadap keseluruhan, dan keadilan khusus (iustitia distributiva) yaitu keadilan dalam menjatuhkan hukum atau ganti rugi atas kejahatan atau pelanggaran. Hugo de Groot atau Grotius (Huijbers, 1984: 62) membedakan dua macam keadilan, yaitu keadilan yang menelusuri (iusitia expletrix /commutative), yaitu menciptakan hak untuk menuntut agar diberikan apa yang termasuk padanya (fakultas), dan keadilan yang memberikan (Iustitia attributrix/ distributiva) yakni tidak menciptakan hak yuridis melainkan hanya suatu hak berupa kepantasan (aptitudo) karena itu keadilan ini sebenarnya tidak termasuk bidang hukum hanya merupakan keharusan moral yang terikat pada keutamaan keutamaan lain dari keadilan seperti kemurahan hati, belas kasihan, dsb. Dengan demikian Grotius menyimpang dari ajaran Aristoteles dan Thomas van Aquinas, yang menentukan keadilan distributif adalah sebagai keadilan sejati yang menuntut agar barang-barang umum dibagikan sesuai dengan jabatan tiaptiap orang dalam masyarakat (Huijbers, 1984: 62).

Menurut etika, keadilan dapat dianggap sebagai budi pekerti individu atau sebagai suatu keadaan terpenuhinya kebutuhan-kebutuhan atau tuntutan-tuntutan manusia secara adil dan layak (Pound, 1954). Etika merupakan usaha manusia untuk memakai akal budi dan daya pikirnya agar dapat menjadi baik. Akal budi itu ciptaan Tuhan yang diberikan kepada manusia untuk digunakan dalam semua dimensi kehidupannya (Magnis-Suseno, 1987: 17). Dengan pertimbangan-pertimbangan akal budi, manusia dapat mengetahui baik dan buruk, boleh dilakukan dan tidak boleh dilakukan, adil dan tidak adil. Dimensi kehidupan manusia itu 
meliputi kebebasan dan tanggung jawab moral (kesadaran, kewajiban dan pengorbanan) dan kebahagiaan. Secara kodrati, manusia bebas menentukan pilihannya dalam memenuhi kebutuhan dan keinginanya tanpa merugikan kepentingan orang lain. Di dalam bertindak senantiasa dilandasi tanggung jawab yang memerlukan kesadaran yaitu keinsyafan (sadar artinya merasa, tahu atau ingat kepada keadaan sebenarnya), kewajiban yaitu sesuatu yang harus dilakukan, dan pengorbanan merupakan titik optimalnya karena memerlukan segalagalanya baik pikiran, perasaan, harta benda, waktu, dan tenaga (Suhendar, dkk, 1993: 216223), sehingga mencapai kebahagiaan dalam hidupnya. Dalam kaitan dengan hal ini, Kaum teleogis termasuk John Stuart Mill merumuskan bahwa perilaku benar adalah sebagai perilaku yang kondusif (favorable) bagi kesejahteraan manusia. Akal budi dapat menunjukan atau paling tidak dalam asasnya, perilaku apa serta bagaimana mendatangkan kebahagiaan manusia dan sejauh itu dapat memandu ke arah perilaku yang benar tadi. Namun akal budi tidak mempunyai kompetensi untuk menentukan apa yang mewujudkan keadilan (hanya bersifat instrumental) sehingga tidak dapat menerangkan hakikat dari kebahagiaan tersebut karena semata-mata ditentukan oleh perasaan. Sebaliknya Kaum deontologis antara lain Immanuel Kant berpendapat bahwa hakikat dari perilaku yang benar dapat diketahui tanpa harus memperhitungkan konsekuensi-konsekuensi bagi kesejahteraan (keuntungan) atau kesusahan (kerugian) manusia serta keyakinan tentang perilaku benar dapat dijustifikasi oleh pemahaman rasional (Rasjidi, dkk, 2001: 149-150). Keadilan ditinjau dari segi ekonomi berkaitan dengan utilitarisma yang mengajarkan tentang kebahagiaan dan tidak adanya kesengsaraan. Hal ini dapat dilihat di Inggris dengan adanya golongan orang yang berpendirian bahwa kehidupan ekonomi harus dibebaskan dari aturan impor dan ekspor yang sempit dari negara. Pandangan mendalam tentang keadilan ditinjau dari segi ekonomi dikemukakan oleh Posner (1981: 48) yang membahas tentang paham utilitarisma dihubungkan dengan teori sosial dan percaya bahwa terdapat suatu kaidah ekonomi (economic norm) yang disebut wealth maximation. Kemudian dari segi politik (Rapar, 1988: 29) berkaitan dengan tujuan negara, salah satu pemikiran yang dikemukakan oleh Merriam (1945: 31) menyebutkan lima hal yang menjadi tujuan negara (Pemerintah), yaitu : external security; internal orde; justice; general welfare; freedom. Keadilan merupakan pranata politik yang diwujudkan dalam suatu sistem dan prosedur yaitu memberikan setiap orang yang telah disepakati serta dianggap patut. Keadilan mengandung sistem nilai (value system) dalam relasi individu agar setiap orang mendapatkan bagiannya berdasarkan nilai tersebut. Sedangkan menurut hukum, pelaksanaan keadilan (administration of justice) mempunyai makna untuk mengatur hubunganhubungan dan menghasilkan prilaku manusia melalui proses pengadilan di masyarakat yang merupakan organisasi politik. Hal ini sejalan dengan pendapat tokoh-tokoh kaum realisme Amerika, seperti Holmes, Jerome Frank, Llewellyn, Cardoso, yang bersikap radikal tentang proses pengadilan karena mereka mengatakan bahwa hakim-hakim tidak saja menemukan hukum tetapi juga membentuk hukum Law as a decision what court do, sehingga Justice is the end of law (Hutagalung, 1999: 40).

Selanjutnya, hakikat keadilan dapat juga dikemukakan berdasarkan aliran-aliran dalam filsafat hukum, yang mengartikan keadilan 
sebagai hubungan yang ideal antar manusia. Aliran hukum alam (natural law) berpendapat bahwa keadilan terdapat dalam ratio Tuhan, mazhab sejarah (historitical yurisprudence) yang dipelopori oleh Carl Von Savigny mengatakan bahwa keadilan itu diwujudkan dalam jiwa bangsa (volksgeist), aliran sociological yurisprudence dari Eugen Ehrlich yang menjelaskan bahwa keadilan itu diwujudkan dalam the living law, aliran marxis yurisprudence yang berpendapat bahwa keadilan tercermin dalam class of ideology, aliran legal positivism yang mengatakan bahwa keadilan terdapat melalui kepastian hukum dalam undang-undang, aliran pragmatic legal realism dari Roscoe Pound yang menjelaskan bahwa keadilan merupakan penjabaran dari Law as a tool of social engineering, dan mazhab UNPAD berpendapat bahwa keadilan adalah pencerminan dari konsep sarana pembangunan (Hutagalung, 1999: 40).

Kemakmuran ditinjau dari segi ekonomi pada hakekatnya adalah terpenuhi kebutuhan hidup secara materil, sehingga apabila hal tersebut tidak dapat atau kurang terwujud, maka disebut miskin (kemiskinan). Meskipun demikian, kemiskinan sukar diukur karena (1). Indikator sosial dan nilai budaya yang berbeda; (2). Jarak geografik antara sumber dan pemakai selalu berbeda; (3). Adanya falsafah yang berbeda tentang faktor waktu; (4). Situasi ekonomi lingkungan yang berbeda (Susanto, 1984: 149).

Badan Koordinasi Keluarga Berencana Nasional (BKKBN, tanpa tahun ) menetapkan kriteria kemiskinan dan keluarga prasejahtera adalah (1). Tidak dapat melaksanakan ibadah menurut agamanya, seluruh anggota keluarga tidak mampu makan dua kali sehari; (2). Seluruh anggota keluarga tidak memiliki pakaian berbeda untuk di rumah, sekolah, bekerja, dan bepergian;(3). Bagian terluas dari rumah berlantai tanah; (4). Tidak mampu membawa anggota keluarga ke sarana kesehatan.

Smith (1977: 16) menjelaskan bahwa kemiskinan hanya dapat diatasi dengan cara meningkatkan ketrampilan dan keakhlian angkatan kerja, meningkatkan ketrampilan dan keakhlian angkatan kerja, dan membantu dalam mengurangi waktu yang diperlukan untuk proses produksi dengan cara tradisional, yaitu dengan menemukan/menyebarkan teknologi yang bersifat mengurangi waktu yang diperlukan untuk proses produksi itu sendiri. Sedangkan Todaro (1977: 62 ) menentukan kriteria keberhasilan pembangunan berdasarkan jaminan masa depan (life sustenance), peningkatan harga diri (self esteem), kebebasan (freedom).

Dengan demikian, dalam ekonomi telah terjadi perubahan persepsi tentang penilaian keberhasilan pembangunan sebagai tolak ukur kemakmuran tidak hanya berdasarkan GNP tetapi lebih banyak pada segi pemenuhan kebutuhan dasar manusia. Sesuai dengan pendapat tersebut, UN-Committee for Development mengajukan pemikiran yang dikenal sebagai indikator kesejahteraan yang didasarkan pada beberapa asumsi kriteria kebutuhan dasar manusia sebagai berikut (1). Kemungkinan umur yang lebih panjang (life expectancy); (2). Angka kematian yang lebih rendah, terutama untuk bayi di bawah umur 1 tahun; (3). Angka persentase bagi warga negara yang dapat membaca huruf latin; dan (4). Pendapatan orang yang meningkat.

\section{Konsepsi Mewujudkan Masyarakat Sejahtera Melalui Pembangunan Nasional berdasar Pancasila}

Kesejahteraan (well being) menurut hedonisme yang antara lain dikemukaan oleh 
Eficurus (filsuf Yunani) serta John Stuart Mill (filsuf Inggris) adalah kehidupan yang penuh sarat dengan kenikmatan. Pandangan lain dari Aristoteles yang dikenal dengan eudemonisme berpendapat bahwa kesejahteraan manusia terdiri atas perwujudan secara aktif dari potensi alamiah atau pembawaan sebagai satu-satunya kemampuan yang membedakan dari binatang. Sedangkan Thomas van Aquino dan filsuf Kristen lainnya berpendapat bahwa kebahagiaan sebagaimana didefinisikan oleh hedonisme dan eudemonisme adalah suatu kesejahteraan manusiawi yang rendah derajatnya (inferior), sehingga untuk menghayati kebahagiaan sejati orang harus menjalankan kebajikan teologikal (sebagai lawan dari kebajikan alamiah) yang meliputi kesetiaan (faith), harapan (hope) dan cinta kasih, serta menempatkan dirinya dalam hubungan dengan Tuhan (Rasjidi, dkk, 2001: 149-150).

Konsep masyarakat yang sejahtera menurut Pancasila dimaksudkan terpenuhinya kebutuhan lahirilah (sandang, pangan dan papan), dan batiniah seperti ketentraman, ketenangan, dan kebahagiaan. Hal itu dapat dicapai dengan adanya pemberian hak untuk mendapatkan kehidupan yang layak bagi kemanusiaan (asas kebutuhan) serta perlakuan yang sama dalam hukum terhadap setiap individu atau warga negara (asas persamaan). Secara teoritis, asas kebutuhan dan persamaan tersebut merupakan ciri yang dianut untuk menentukan kriteria keadilan (Syahrani, 1999: 21).

Sedangkan keadilan itu sendiri merupakan salah satu tujuan hukum, karena suatu sistem hukum positif harus berdasarkan keadilan, meskipun makna keadilan berbedabeda dari suatu sistem nilai ke sistem nilai lainnya, namun suatu sistem hukum tidak dapat bertahan lama apabila tidak dirasakan adil oleh masyarakat yang diatur oleh hukum itu. Dengan kata lain, ketidakadilan akan mengganggu ketertiban yang justru menjadi tujuan tatanan hukum tersebut. Ketertiban yang terganggu berarti bahwa keteraturan dan kepastian tidak lagi terjamin, sehingga suatu tatanan hukum tidak dapat dilepaskan dari keadilan (Kusumaatmadja, dkk, 2000: 52). Dengan demikian, terdapat keterkaitan yang erat antara mewujudkan masyarakat yang sejahtera dengan tujuan hukum yaitu keadilan.

Teori pertama yang dapat digunakan untuk menjelaskan keterkaitan antara kesejahteraan dan tujuan hukum (keadilan) yaitu teori etis (etische theorie) yang berpendapat bahwa hukum hanya sematamata bertujuan mewujudkan keadilan. Teori ini pada mulanya dikemukakan oleh filusuf Yunani yaitu Aristoteles dalam karyanya Ethica Nicomachea dan Rhetorik (Utrecht, 1957: 20), yaitu hukum mempunyai tugas yang suci yaitu memberi kepada orang yang berhak menerimanya. Kelemahan teori ini adalah bahwa hukum tidak selalu mewujudkan keadilan, tetapi mengutamakan ketertiban, keteraturan, atau kelancaran, seperti misalnya ketentuan hukum tentang lalu lintas yang mewajibkan setiap kendaraan menggunakan jalur sebelah kiri (Mertokusumo, 1986: 60).

Teori kedua adalah teori kegunaan (utilities theorie) dari Jeremy Bentham seorang akhli hukum dari Inggris berpendapat bahwa hukum bertujuan menjamin adanya kegunaan atau manfaat bagi kelompok masyarakat untuk mencapai sebesar-besarnya kebahagiaan (the greatest happiness for the greatest number). Namun teori ini juga mempunyai kelemahan yaitu hanya memperhatikan hal-hal yang bersifat umum, dan terlalu individualistis sehingga tidak memberikan kepuasan bagi perasaan hukum (Utrecht,1957: 20), tidak 
cocok dengan Pancasila yang memberikan kebahagiaan melalui keadilan untuk seluruh rakyat Indonesia bukan sekelompok mayoritas. Menurut Bentham, hakikat kebahagiaan adalah kenikmatan kehidupan yang bebas dari kesengsaraan, sehingga tujuan manusia melakukan suatu tindakan adalah untuk mendapatkan kebahagiaan sebesar-besarnya dan mengurangi penderitaan. Baik buruknya tindakan diukur dari baik-buruknya akibat yang dihasilkan oleh tindakan itu. Suatu tindakan dinilai baik, jika menghasilkan kebaikan dan sebaliknya dinilai buruk apabila mengakibatkan kerugian (Utrecht,1957: 79). Bentham menerapkan teori ini secara analogis pada bidang hukum yaitu baik buruknya hukum harus diukur dari akibat yang dihasilkan oleh penerapan hukum itu. Suatu ketentuan hukum dinilai baik, jika akibat yang dihasilkan dari penerapannya adalah kebaikan, kebahagiaan sebesar-besarnya dan berkurang penderitaan. Sebaliknya dinilai buruk, jika penerapannya menghasilkan akibat yang tidak adil, kerugian dan hanya memperbesar penderitaan. Teori analogi ini bermanfaat bagi pengembangan ilmu hukum, yaitu untuk mengukur kualitas dari peraturan perundangundangan (Utrecht,1957: 79).

Teori ketiga, merupakan campuran dari kedua teori tersebut di atas yang dikemukakan oleh para akhli seperti Bellefroid yang mengatakan bahwa isi hukum harus ditentukan menurut dua asas yaitu keadilan dan faedah (Utrecht,1957: 79). Kemudian Gustav Radbruch berpendapat bahwa tujuan hukum meliputi keadilan, kegunaan, dan kepastian hukum (Salman, 1987: 11). Tokoh teori campuran lainnya adalah Apeldoorn (1983: 20) yang berpendapat tujuan hukum mempertahankan kedamaian dengan mengadakan keseimbangan antara kepentingan yang dilindungi dan setiap orang harus memperoleh sedapat mungkin yang menjadi haknya (Syahrani, 1999: 25). Kedamaian adalah suatu keadaan yang meliputi dua hal, yaitu ketertiban atau keamanan (orde) dan ketentraman atau ketenangan (rust). Ketertiban tertuju pada hubungan lahiriah, dengan melihat pada proses interaksi antar pribadi dalam masyarakat. Adapun ciri-ciri ketertiban antara lain adalah adanya kerjasama; stabilitas; keseragaman; konformitas; dan tidak ada konflik yang negatif (Syahrani, 1999: 25). Sedangkan ketentraman mengarah pada keadaan batin yaitu melihat pada kehidupan batiniah masing-masing pribadi dalam masyarakat (Purbacaraka, dkk, 1978: 30). Ciri-cirinya antara lain adalah tidak ada bahaya dari luar; tidak ada rasa khawatir; tidak ada konflik pribadi; dan adanya lembaga-lembaga penyalur ketegangan (Syahrani,1999: 26). Dalam ketertiban lebih menonjol kewajiban, sedangkan pada ketentraman yang diutamakan adalah hakhaknya. Manusia memerlukan keduanya dalam wujud yang serasi karena terlalu menekankan kepada ketertiban membuka jalan kearah keadaan totaliter, sedangkan lebih mementingkan ketentraman membuka jalan ke arah anarkhi (Syahrani,1999: 26).

Untuk menciptakan kedamaian dalam arti tertib (bersifat lahirilah dan menimbulkan kewajiban) serta ketentraman (bersifat batiniah dan memberikan hak) agar dapat berjalan dengan seimbang dan serasi yang dinamis perlu adanya faktor penjamin yang disebut hukum (Badan Pembinaan Hukum Nasional, 1980: 61). Kemudian akhli lainnya yang dapat dikategorikan sebagai tokoh teori campuran adalah Kusumaatmadja yang mengatakan : 
Hukum tidak hanya meliputi asas dan kaidah yang mengatur kehidupan manusia dalam masyarakat, melainkan juga termasuk lembaga dan proses dalam mewujudkan berlakunya kaidah itu dalam kenyataan di masyarakat (Kusumaatmadja, 2002: vi).

Kalau dianalisis lebih lanjut, makna definisi tersebut mengandung aliran atau mazhab dalam filsafat hukum, yaitu: kata asas berarti memperhatikan pandangan aliran hukum alam, karena asas itu ada kaitannya dengan nilai-nilai moral tertinggi yaitu keadilan. Sedangkan kata kaidah berarti memperhatikan pengaruh aliran positivisme hukum, karena mempunyai sifat normatif, seperti yang dikemukakan oleh John Austin dan Hans Kelsen. Kata lembaga berarti menggambarkan pandangan mazhab sejarah, karena yang dimaksud adalah lembaga hukum adat sebagai cerminan pengaruh mazhab sejarah. Kata proses, berarti memperhatikan pandangan pragmatic legal realism (Roscoe Pound) yaitu proses terbentuknya putusan hakim pengadilan. Lebih lanjut kata lembaga dan proses menggambarkan pandangan sosiological jurisprudence, karena merupakan cerminan dari living law , yaitu sumber hukum tertulis dan tidak tertulis yang hidup (formal).

Kemudian dikatakan pula bahwa tujuan hukum adalah tujuan pokok dan pertama kali dari hukum adalah ketertiban. Kebutuhan akan ketertiban ini syarat pokok (fundamental) bagi adanya suatu masyarakat manusia yang teratur. Di samping ketertiban, tujuan lain dari hukum adalah tercapainya keadilan yang berbeda-beda isi dan ukurannya menurut masyarakat dan zamannya (Kusumaatmadja, 2002: 3-4).

Selanjutnya Mochtar Kusumaatmadja mengatakan bahwa hukum dapat berfungsi sebagai sarana pembaharuan masyarakat sebagai modifikasi konsep Roscoe Pound Law as a tool of social engeneering yang merupakan inti pemikian dari aliran pragmatic legal realism serta dikaitkan pula dengan flsafat budaya dari Northop dan policy oriented dari Laswell dan Mc Dougal (Rasjidi, dkk, 2001: 78-79). Konsepsi hukum sebagai sarana pembaharuan masyarakat lebih luas jangkauan dan ruang lingkupnya daripada di Amerika tempat kelahirannya karena lebih menonjolnya perundang-undangan dalam proses pembaharuan hukum di Indonesia meskipun yurisprudensi tetap memegang peranan pula dan ditolaknya aplikasi mekanisme dari konsepsi tersebut, yaitu penggunaan istilah tool karena akan mengakibatkan hasil yang sama dari penerapan faham legisme yang banyak ditentang di Indonesia (Rasjidi, dkk, 2001: 78-79). Agar dalam pelaksanaan perundang-undangan yang bertujuan untuk pembaharuan itu dapat berjalan sebagaimana mestinya, hendaknya diselaraskan dengan inti pemikiran aliran sociological jurisprudence yaitu hukum yang baik adalah sesuai dengan hukum yang hidup di dalam masyarakat dalam arti mencerminkan nilai-nilai yang hidup di masyarakat (Rasjidi, dkk, 2001: 80). Sedangkan Kantaatmadja (1985) menjelaskan hukum sebagai sarana pembaharuan mengandung arti bahwa hukum harus mampu memenuhi kebutuhan sesuai dengan tingkat kemajuan serta tahapan pembangunan di segala bidang, sehingga dapat diciptakan ketertiban dan kepastian hukum untuk memperlancar pelaksanaan pembangunan. Pembangunan dalam arti seluas-luasnya meliputi segala segi kehidupan masyarakat, karena itu istilah pembangunan ekonomi sebenarnya kurang tepat, karena tidak dapat membangun ekonomi suatu masyarakat tanpa mengaitkan dengan 
kehidupan lainnya (Kusumaatmadja, 2002: 19). Pembangunan ekonomi adalah usahausaha untuk meningkatkan taraf hidup suatu bangsa yang seringkali diukur dengan tinggi rendahnya pendapatan riel perkapita sehingga tujuan pembangunan ekonomi disamping untuk menaikan pendapatan nasional riel juga meningkatkan produktivitas (Irawan, dkk, 1997). Todaro (1981: 96-97) mendefinisikan pembangunan ekonomi sebagai suatu proses multidimensional yang mencakup perubahan struktur, sikap hidup dan kelembagaan, selain mencakup peningkatan petumbuhan ekonomi, pengurangan ketidakmerataan distribusi pendapatan dan pemberantasan kemiskinan. Dengan demikian inti dari tujuan pembangunan ekonomi adalah pemenuhan kebutuhan hidup manusia (kemakmuran). Untuk menjelaskan hal itu, dapat dikemukakan teori-teori pembangunan ekonomi seperti aliran klasik yang dipelopori oleh Adam Smith, Davis Ricardo dan Thomas Robert Malthus (Irawan, dkk, 1997: 16-21).

Adam Smith menjelaskan bahwa perkembangan ekonomi diperlukan adanya spesialisasi atau pembagian kerja agar produktivitas tenaga kerja bertambah yang sebelumnya harus ada akumulasi kapital dari dana tabungan. Pasar harus seluas mungkin agar dapat menampung hasil produksi sehingga perdagangan internasional berkembang. Kenaikan produktivitas akan menaikan penghasilan nasional sekaligus memperbesar jumlah penduduk, serta mengakibatkan upah naik dan terjadinya akumulasi kapital. Namun sumber daya alam terbatas maka keuntungan menurun karena berlakunya hukum pertambahan hasil yang semakin berkurang, sehingga perkembangan mengalami kemacetan atau berhenti. David Ricardo berpendapat, bila jumlah penduduk bertambah terus dan akumulasi kapital terus menerus terjadi, maka tanah yang subur menjadi semakin langka .Akibatnya berlaku hukum tambahan hasil yang semakin berkurang ditambah lagi persaingan diantara kapitalis dalam mengolah tanah tersebut sehingga mengakibatkan keuntungan semakin menurun sampai tingkat yang normal. Sedangkan Thomas Robert Malthus menguraikan tentang jumlah penduduk yang terus menerus merupakan unsur yang perlu untuk adanya tambahan permintaan. Namun kenaikan jumlah penduduk saja tanpa disertai kemajuan faktor atau unsur perkembangan yang lain tidak akan menaikan pendapatan atau permintaan, justru akan menurunkan tingkat upah dan berarti pula merendahkan biaya produksi. Turunnya biaya produksi akan memperbesar keuntungan para kapitalis dan mendorong untuk terus berproduksi, tetapi keadaan ini hanya sementara saja sifatnya, sebab permintaan efektif (effective demand) akan semakin berkurang karena pendapatan buruh juga semakin berkurang. Hal ini berlainan dengan pendapat J.B Say yang terkenal dengan hukum pasarnya supply creates its own demand, artinya asal jumlah produksi bertambah maka secara otomatis permintaan ikut bertambah pula karena pada hakikatnya kebutuhan manusia tidak terbatas (Irawan, dkk, 1997: 16-21).

Teori lainnya tentang pembangunan ekonomi adalah aliran neo-klasik yang mempelajari tingkat bunga, yaitu harga yang menghubungkan nilai pada saat yang akan datang dan pada akhirnya sampai pada masalah akumulasi modal (Irawan, dkk, 1997: 27).

Berdasarkan teori-teori tersebut di atas, dapat disimpulkan bahwa pada umumnya aspek pembangunan ekonomi sebagai tolak 
ukur untuk mencapai tingkat kemakmuran berdasarkan pada pemenuhan materi yaitu kaitan antara kapital, produksi, permintaan dan penawaran. Sedangkan menurut Pancasila, makmur diartikan sebagai pemenuhan kebutuhan manusia baik materil maupun spiritual, jasmaniah maupun rohaniah. Secara luas makmur (kemakmuran) adalah tercapainya tingkatan harkat dan martabat yang lebih tinggi sesuai dengan unsur kodrat manusia (Kaelan, 2000: 67). Dengan demikian hakikat kemakmuran berdasarkan Pancasila tidak hanya mempunyai dimensi ekonomi tetapi juga psikologi yaitu terpenuhinya kebutuhan spiritual/rohaniah seperti ketenangan, ketentraman dan kebahagiaan. Selain itu, juga berdimensi sosial yaitu adalah tercapainya kedudukan yang terhormat dalam arti memberikan derajat yang tinggi sebagai makhluk sosial dan makhluk Tuhan dalam kerangka Negara Kesatuan Republik Indonesia.

Keterkaitan antara kemakmuran sebagai inti pembangunan ekonomi dengan pembangunan hukum dijelaskan oleh Sunaryati Hartono sebagai berikut :

Pembangunan ekonomi mempunyai hubungan yang erat dan pengaruh timbal balik dengan pembangunan hukum, karena pembaharuan dasar-dasar pemikiran dibidang ekonomi mengubah dan menentukan dasar-dasar pembangunan hukum yang bersangkutan, sebaliknya penegakan asas-asas hukum yang sesuai juga akan memperlancar terbentuknya struktur ekonomi yang dikehendaki. Tetapi sebaliknya, penegakan asas-asas hukum yang tidak sesuai justru akan menghambat terciptanya struktur ekonomi yang dicita-citakan. Itulah sebabnya, maka dalam rangka usaha menuju struktur ekonomi Pancasila, kaidah-kaidah hukum yang melandasinya juga benar-benar mencerminkan nilai-nilai yang dijunjung tinggi oleh Pancasila. Dengan kata lain, bahwa sistem hukum nasional Indonesia harus menjadi suatu sistem hukum Pancasila dan hukum ekonomi nasional Indonesia merupakan bagian dari Hukum Pancasila (Hartono, 1988: 6).

Lebih lanjut Sunaryati Hartono menjelaskan tentang makna dari pembangunan hokum, yaitu (1). Menyempurnakan (membuat sesuatu yang lebih baik ), (2). Mengubah agar menjadi lebih baik dan modern, (3). Mengadakan sesuatu yang sebelumnya belum ada, atau (4). Meniadakan sesuatu yang terdapat dalam sistem lama, karena tidak diperlukan atau tidak cocok dengan sistem baru (Hartono, 1991).

Manan (2000: 2) menjelaskan bahwa salah satu visi pembangunan hukum nasional adalah guna memenuhi kebutuhan individu, masyarakat (bangsa), dan negara untuk mewujudkan kesejahteraan umum atas dasar keadilan sosial bagi seluruh rakyat Indonesia. Sedangkan misi pembangunan hukum nasional adalah memantapkan sistem hukum nasional yang telah ada untuk mewujudkan perikehidupan bermasyarakat, berbangsa, dan bernegara dalam wadah negara RI yang demokratis dan berdasarkan hukum, aman, tentram, tertib, damai, bahagia, sejahtera menurut dasar keadilan sosial bagi seluruh rakyat Indonesia.

Selanjutnya materi pembangunan hukum nasional menyangkut struktur hukum (misalnya peradilan), substansi hukum (perundang-undangan), dan budaya hukum (persepsi dan apresiasi masyarakat terhadap hukum) (Manan, 2000: 2) serta pembentukannya mengutamakan asas-asas umum yang diterima bangsa-bangsa tanpa meninggalkan hukum adat yang masih 
berlaku dan relevan dengan kehidupan modern (Kusumaatmadja, 2002: 187).

Secara politis sangat penting, bahwa pembangunan hukum nasional diarahkan pada asas-asas yang merupakan pencerminkan dari tekad dan aspirasi sebagai bangsa yang terkandung dalam Undang-Undang Dasar 1945 dan Pembukaannya sebagai pencerminan dari falsafah Pancasila. Karena itu setiap hukum nasional harus mengandung asas-asas yang sesuai dengan sila-sila di dalam Pancasila, yaitu asas ketuhanan, asas kemanusiaan, asas persatuan dan kesatuan, asas demokrasi, serta asas keadilan sosial (Kusumaatmadja, 2002: 187).

Sejalan dengan hal itu, Sidharta (2003: 3) menjelaskan bahwa penerapan atau realisasi Pancasila pada bidang-bidang kehidupan hukum itu menumbuhkan hukum yang dijiwai atau diwarnai oleh Pancasila. Keseluruhan tata hukum sebagai suatu sistem aturan hukum positif yang merupakan penjabaran atau penerapan Pancasila pada bidang hukum, dapat disebut Hukum Pancasila. Hukum Pancasila sebagai hukum positif tumbuh dari dalam dan atau dibuat oleh rakyat Indonesia untuk mengatur dan mewujudkan ketertiban yang adil dalam kehidupan kemasyarakatan di Indonesia, sehingga Hukum Pancasila dapat juga disebut hukum (nasional) Indonesia. Proses terbentuknya peraturan-peraturan hukum positif itu dapat melalui tindakan nyata para warga masyarakat dalam menjalani kehidupan sehari-hari, maka terbentuklah hukum tidak tertulis. Proses terbentuknya peraturan hukum tersebut dapat juga terjadi secara disengaja melalui keputusan-keputusan para pejabat, yurisprudensi dan perundangundangan. Produk dari keseluruhan proses pembentukan peraturan hukum positif itu mewujudkan tata hukum. Hakikat Hukum
Pancasila membicarakan tentang gagasan atau cita hukum (the idea of law, rechtidee) dalam alam pikiran berdasarkan Pancasila (Sidharta (2003: 3). Mahfud MD (1998: 59) menjelaskan bahwa Pancasila sebagai citacita hukum berarti berkedudukan sebagai staatsfundamentalnorm dalam negara Indonesia yang mempunyai fungsi konstitutif maupun regulatif. Pancasila sebagai fungsi konstitutif menentukan dasar suatu tata hukum, sedangkan fungsi regulatif adalah menentukan hukum positif itu adil atau tidak. Sebagai staatsfundamentalnorm, Pancasila adalah pangkal tolak derivasi (sumber penjabaran) dari tertib hukum di Indonesia termasuk UUD 1945, sehingga merupakan sumber dari segala peraturan perundang-undangan di Indonesia. Lebih Lanjut, Sidharta (2003: 3) menjelaskan bahwa hukum yang dijiwai oleh Pancasila adalah berasaskan semangat kerukunan. Karena itu juga hukum secara langsung diarahkan untuk mewujudkan keadilan sosial yang memberikan kepada masyarakat sebagai kesatuan dan masing-masing warga masyarakat memperoleh kesejahteraan (materil dan spiritual) yang merata dalam keseimbangan yang proporsional. Terpaut pada asas kerukunan adalah asas kepatutan. Asas ini juga adalah tentang cara menyelenggarakan hubungan antar warga masyarakat yang di dalamnya diharapkan berperilaku pantas sesuai dengan kenyataan sosial. Selain itu, dalam melaksanakan hak dan kewajiban yang sah menurut hukum, warga masyarakat diharapkan untuk memperhatikan kepantasan, yakni berprilaku sedemikian rupa sehingga tidak merendahkan martabatnya sendiri dan atau orang lain (Sidharta, 2003: 3). Sifat lain yang memberikan ciri Hukum Pancasila adalah asas keselarasan. Asas ini menghendaki harmoni dalam kehidupan bermasyarakat 
sehingga penyelesaian masalah-masalah konkrit, selain harus didasarkan pada pertimbangan kebenaran dan kaidah hukum yang berlaku, juga harus diakomodasikan pada proses kemasyarakatan sebagai keseluruhan yang utuh dengan mempertimbangkan perasaan yang hidup dalam masyarakat. Karena itu warga masyarakat dan pelaksana hukum diharapkan melaksanakan hak dan kewajiban secara patut, sehingga kerukunan dan kesejahteraan bermasyarakat dapat dipertahankan dan dikembangkan (Sidharta, 2003: 3). Asas kerukunan, asas kepatutan dan asas keselarasan sebagai ciri khas Hukum Pancasila dapat dicakup dengan satu istilah, yakni sifat kekeluargaan. Karena itu dapat dikatakan bahwa hukum pancasila adalah hukum bersemangat kekeluargaan menunjuk pada sikap berdasarkan kepribadian setiap warga yang diakui dan dilindungi oleh masyarakat. (Sidharta, 2003:3). Tujuan Hukum Pancasila adalah untuk mewujudkan ketertiban dan keteraturan, kedamaian, serta keadilan yang dirumuskan dengan istilah pengayoman (perlindungan) dalam arti tidak hanya bersifat pasif, yakni mencegah tindakan sewenangwenang dan pelanggaran hak melainkan juga bersifat aktif, artinya meliputi upaya dalam menciptakan kondisi dan mendorong manusia untuk selalu memanusiakan diri terus menerus. Jadi dalam Pancasila, tujuan hukum adalah menciptakan kondisi sosial yang manusiawi sehingga memungkinkan proses berlangsung secara wajar, dan setiap manusia mendapat kesempatan yang seluas-luasnya untuk mengembangkan seluruh potensi kemanusiaannya secara utuh, memelihara dan mengembangkan budi pekerti serta cita-cita moral yang luhur berdasarkan Ketuhanan Yang Maha Esa (Sidharta, 2003: 3). Pancasila sebagai suatu nilai merupakan sumber dari segala penjabaran norma baik norma hukum, norma moral maupun norma kenegaraan lainnya. Dalam filsafat Pancasila terkandung di dalamnya suatu pemikiran yang bersifat kritis, mendasar, rasional, sistematis dan komperhensif (menyeluruh). Karena itu suatu pemikiran filsafat tidak secara langsung menyajikan noma-norma yang merupakan pedoman dalam tindakan atau aspek praksis melainkan nilai-nilai yang bersifat mendasar. Sebagai suatu nilai, pancasila memberikan dasar-dasar yang bersifat fundamental dan universal bagi manusia dalam hidup bermasyarakat, berbangsa, dan bernegara. Apabila nilai-nilai tersebut kemudian dijabarkan dalam kehidupan yang bersifat praksis atau kehidupan yang nyata maka nilai-nilai tersebut merupakan suatu norma yang jelas, sehingga merupakan suatu pedoman. Norma-norma tersebut meliputi (1). Norma moral yang berkaitan dengan tingkahlaku manusia yaitu baik dan buruk. (2). Norma hukum yaitu suatu sistem peraturan perundang-undangan yang berlaku sehingga pancasila merupakan sumber segala sumber hukum (Kaelan, 2000: 172). Pandangan dan tingkatan nilai tersebut menurut Notonagoro dibedakan menjadi tiga macam, yaitu (1). Nilai materil yaitu segala sesuatu yang berguna bagi jasmani, (2). Nilai vital, yaitu segala sesuatu yang berguna bagi manusia untuk melakukan aktivitas, dan (3). Nilai kerokhanian yaitu segala sesuatu yang berguna bagi rokhani manusia, yang dapat dibedakan atas empat tingkatan sebagai berikut (1). Nilai kebenaran, yaitu bersumber pada akal, rasio, budi atau cipta manusia; (2). Nilai keindahan atau estetis, yaitu nilai yang bersumber pada perasaan manusia; (3). Nilai kebaikan atau nilai moral, yaitu nilai yang bersumber pada unsur kehendak (will, wollen, karsa) manusia; 
(4). Nilai religius yang merupakan nilai kerokhanian tertinggi dan bersifat mutlak yang berhubungan dengan kepercayaan dan keyakinan manusia bersumber pada wahyu dari Tuhan Yang Maha Esa (Kaelan, 2000: 169). Lebih lanjut Notonagoro mengatakan bahwa nilai-nilai Pancasila termasuk nilai kerokhanian yang mengakui nilai materil, dan nilai vital. Dengan demikian nilai-nilai Pancasila yang tergolong nilai kerokhanian itu juga mengandung nilai-nilai lain secara lengkap dan harmonis, yaitu nilai materil, nilai vital, dan nilai kebenaran, nilai keindahan atau estetis, nilai kebaikan atau nilai moral, maupun nilai kesucian secara keseluruhan bersifat sistematik-hirarkhis, yaitu sila pertama Ketuhanan Yang Maha Esa sebagai basisnya sampai dengan sila Keadilan Sosial sebagai tujuannya (Kaelan, 2000: 169). Dengan demikian, nilai-nilai di dalam Pancasila mengandung cita-cita bangsa Indonesia yang diwujudkan dalam kehidupannya, yaitu adil dan makmur sebagai landasan hidup menuju masyarakat sejahtera lahir batin melalui pembangunan nasional.

\section{SIMPULAN}

Berdasar perjelasan tersebut di atas dapat ditarik simpulan sebagai berikut.

Pertama, keadilan dapat ditinjau dari berbagai sudut pandang, yaitu hukum, etika, politik, dan ekonomi, sehingga pembangunan untuk mencapai kemakmuran yang adil dan merata serta menyeluruh mengandung arti pemenuhan kebutuhan manusia yang bukan hanya berdimensi ekonomi saja, tetapi juga hukum, politik, psikologis dan sosial. Dengan demikian, pendekatan untuk memahami keadilan bersifat multidiemsi.

Kedua, hakikat adil dan makmur sebagai landasan hidup berdasarkan Pancasila adalah melakukan pembangunan di segala bidang untuk mewujudkan keadilan sosial dan kemakmuran sosial untuk seluruh rakyat Indonesia secara proporsional dan merata yang dijiwai oleh sila-sila lainnya sebagai suatu kesatuan yang bulat dan utuh. Berdasarkan hal itu, untuk mencapai adil dan makmur diperlukan upaya melakukan perubahan kearah yang lebih baik (pembangunan).

Selanjutnya disarankan hal-hal sebagai berikut.

Pertama, perlu kesadaran seluruh warga masyarakat untuk berperan serta dalam pembangunan sesuai dengan profesi masingmasing untuk mewujudkan adil dan makmur agar tercapai kesejahteraan bersama karena hal itu bukan hanya tugas pemerintah saja, tetapi juga hak dan kewajiban seluruh rakyat Indonesia.

Kedua, Pancasila merupakan landasan filosofis karena itu untuk menjabarkan lebih lanjut hakikat adil dan makmurperlu dituangkan dalam bentuk perundang-undangan, yaitu Hukum Pancasila yang dilandasi 5 (lima) asas yang dikandungnya serta harus memperhatikan sistem-sistem hukum yang hidup sehingga usaha untuk mencapai kepastian hukum menuju pembangunan masyarakat sejahtera lahir batin dapat tercapai.

\section{DAFTAR PUSTAKA}

Apeldoorn, R.J.Van, 1983, Inleiding tot de Studie van het Nederlands Recht, diterjemahkan oleh Oetarid Sadino, Pradnya Pramita.

Badan Koordinasi Keluarga Berencana Nasioonal ( BKKBN ), tanpa tahun

Badan Pembinaan Hukum Nasional, 1980, Hasil Seminar Nasional, Jakarta.

Dias, R.W.M, 1976, Jurisprudence, London: Butterworths, 
Friedmann, W, 1960, Legal Theory, Steven and Sons Limited, London., fourth Edition.

Hartono, Sunaryati, 1988, Hukum Ekonomi Pembangunan Indonesia, Binacipta.

Perkembangan Hukum Nasional Indonesia Menuju Sistem Hukum Nasional”, Makalah.

Huijbers, Theo, 1984, Filsafat Hukum dalam Lintasan Sejarah, Yogyakarta: Yayasan Kanisius.

Hutagalung, Thoga H., 1999, Peranan Hukum dan Keadilan Dalam Pembangunan Masyarakat Yang Sejahtera, Bandung: Armico.

Irawan dan M. Suparmoko, 1997, Ekonomika Pembangunan, edisi 5, BPFE- Yogyakarta.

Kaelan, 2000, Pendidikan Pancasila, Yogyakarta: Paradigma.

Kantaatmadja, Komar, 1985, "Peran dan Fungsi Profesi Hukum dalam Undang_Undang Perpajakan", Makalah Seminar Nasional Hukum Pajak, Bandung. IMNOUNPAD.

Kusumaatmadja, Mochtar dan B. Arief Sidharta, 2000, Pengantar Ilmu Hukum, Bandung: Alumni.

Kusumaatmadja, Mochtar, 2002, KonsepKonsep Hukum Dalam Pembangunan Nasional, , Bandung: Alumni.

Lee,K.D.P, 1960, Plato The Republic, Penguin Books.

Magnis-Suseno, Frans, 1987, Etika Dasar, Yogyakarta: Kanisius.

Mahfud M.D, 1998,"Pancasila Sebagai Paradigma Pembaharuan Hukum", Jurnal Filsafat Pancasila, Yogyakarta; Universitas Gajahmada.
Manan, Bagir, 2000, "Pembangunan Hukum untuk Mewujudkan Keadilan dan Kebenaran", Makalah.

Merriam, Charles E, 1945, Systematic Politics, University Of Chicago Press.

Mertokusumo, Sudikno, 1986, Mengenal Hukum, Yogyakarta.

Posner, Richard A, 1981, The Economic of Justice, Harvard University.

Pound, Roscoe, 1954, An Introduction to the Philosophy of Law, Yale University Press.

Purbacaraka, Purnadi dan Soerjono Soekanto,1978, Perihal Kaedah Hukum, Cet. I, Bandung:Alumni.

Rapar, J.H., 1988, Filsafat Politik Aristoteles, Jakarta, Rajawali Pers 1998, Filsafat Politik Plato, Jakarta: Rajawali Pers.

Rasjidi, Lili dan Ira Rasjidi, 2001, DasarDasar Filsafat dan Teori Hukum, Bandung; Citra Aditya Bakti.

Sabine, George H, 1977, Teori Politik, Judul asli : A History of Political Theory, terjemahan Soewarno Hadiatmodjo, Binacipta.

Salman, Otje, 1987, Ikhtisar Filsafat Hukum, Bandung: Armico,

Sidharta, B. Arief, 2003-2004, "Filsafat Hukum Pancasila", Materi Kuliah Sistem Filsafat Hukum Indonesia, Program Pascasarjana UNPAD.

Smith, David M, 1977, Where the Grass is Greener, Penguin Books, MiddlesexLondon- New York.

Suhendar, M.E \& Pien Supinah, 1993, Ilmu Budaya Dasar, Pionir Jaya.

Syahrani, Riduan, 1999, Rangkuman Intisari Ilmu Hukum, Bandung: Citra Aditya Bakti, 
Sudjana -- Hakikat Adil dan Makmur Sebagai Landasan Hidup dalam Mewujudkan Ketahanan untuk Mencapai Masyarakat Sejahtera Melalui Pembangunan Nasional Berdasarkan Pancasila

Todaro, MichaelP., 1977,Economic Development in the Third World; An Introduction to Problem and Policies in Global Perspective, London- New York, 1977. 1981, Economic For A Developing World, Longman.
Utrecht, 1957, Pengantar Dalam Hukum Indonesia, Cet. IV, Ikhtiar.

\section{Peraturan Perundangan}

Undang-Undang Dasar 1945 setelah Amandemen ke 4 